\title{
Muhasebe Meslek Mensuplarını Hile Eylemine Yönelten Psikolojik ve Ekonomik Faktörler
}

\section{The Psychological and Economic Factors Directing/Forcing The Accounting Professionals into Fraudulent Action}

\author{
Mehmet Demir, ${ }^{a}$ Öznur Arslan b,* \\ a Prof. Dr., Sivas Cumhuriyet Üniversitesi, İktisadi İdari Bilimler Fakültesi, Bankacılık Finans Bölümü, Sivas/Türkiye \\ ORCID: 0000-0003-1796-7974 \\ b Dr. Öğretim. Üyesi, Sivas Cumhuriyet Üniversitesi, Cumhuriyet Sosyal Bilimler Meslek Yüksekokulu, Büro Hizmetleri ve Sekreterlik Bölümü, \\ Hukuk Büro Programı, Sivas/Türkiye \\ ORCID: 0000-0001-5973-9107
}

\section{MAKALE BİLGİSİ}

\section{Makale Geçmişi:}

Başvuru tarihi: 21 Aralık 2019

Düzeltme tarihi: 27 Şubat 2020

Kabul tarihi: 12 Mart 2020

\section{Anahtar Kelimeler:}

Hile Eylemi

Muhasebe Meslek Mensubu,

Mükellef

Psikolojik ve Ekonomik Faktörler

\section{ARTICLE INFO}

\section{Article history:}

Received 21 December 2019

Received in revised form 27 February 2020

Accepted 12 March 2020

Keywords:
Fraudulent Activity
Accounting Professional
Taxpayer
Psychological, and Economic Factors

ÖZ

Bu çalışmada hile olgusu öncelikle psikolojik ve ekonomik açılardan ele alınmış ardından konuyla ilgili ampirik çalışmalardan yararlanılarak muhasebe meslek mensuplarını hile eylemine yönelten/zorlayan psikolojik ve ekonomik faktörler saptanmaya çalışılmıştır.

Literatür taraması sonucunda meslek mensuplarını hileli davranışa yönelten/zorlayan psikolojik ve ekonomik birçok faktör olduğu tespit edilmiştir. Bunlar içinde "mükellef baskısı yaşamak, daha az vergi ödetilmesi talebiyle karşılaşmak, asgari ücret tarifesinin altında hizmet vermeye zorlanmak, muhasebecilik ücretini tahsil edememek, meslektaşların yanlış uygulamaları, müşteri kaybetme korkusu yaşamak, mali tabloların manipüle edilmesi talebiyle karşılaşmak, kayıt dışı ekonominin varlığı ve vergi oranlarının yüksekliği” gibi faktörlerin meslek elemanlarını hile eylemine yönelten/zorlayan psikolojik ve ekonomik faktörler olarak öne çıktığı görülmektedir.

\section{Giriş}

Muhasebe, sosyal ve ekonomik hayatı etkileyen bilgiler üretmektedir. Muhasebenin ürettiği bu bilgiler, işletme sahiplerini, çalışanları, kredi kuruluşlarını, yatırımcıları, devleti ve dolayısıyla tüm toplumu ilgilendirdiği için kaliteli olması gerekir. Kaliteli muhasebe bilgisinin ise muhasebenin temel kavramları ve ilkeleri, muhasebe standartları ve ilgili mevzuat hükümleri çerçevesinde hareket edildiğinde ortaya çıkacağı şüphesizdir. Muhasebe bilgi üretim sürecinin aşamalarında, belirtilen hususlara uyulmaması durumunda muhasebe bilgilerinin kalitesi düşmekte ve bilgi kullanıcıları olumsuz etkilenmektedir.

Muhasebe bilgi kalitesini sağlayan ve üst noktalara taşıyan aktörlerden en önemlisi kuşkusuz muhasebe meslek mensuplarıdır. Fakat muhasebe meslek mensupları mesleklerini icra ederlerken çeşitli psikolojik ve ekonomik

\footnotetext{
* Sorumlu yazar/Corresponding author. e-posta: oznurkul@cumhuriyet.edu.tr
} 
baskılara maruz kalmak suretiyle hileli işlem yapmaya zorlanmaktadırlar.

$\mathrm{Bu}$ çalışmada hile olgusu öncelikle psikolojik ve ekonomik açılardan ele alınmış ardından konuyla ilgili ampirik çalışmalardan yararlanılarak muhasebe meslek mensuplarını hile eylemine yönelten psikolojik ve ekonomik faktörler saptanmaya çalışılmıştır.

\section{Hile Eylemi}

Bir kişiye veya kuruma zarar vermenin öne çıkan iki yolu vardır. Birincisi cebren ve güç kullanmak, ikincisi ise sahtekârlık veya aldatmaktır. Burada yer alan ilk eylem, hırsızlık veya soygun; ikinci eylem ise hile veya yolsuzluk olarak adlandırılmaktadır. Hile, kasıt taşıyan bir davranıştır ve bu yönüyle hatadan ayrılır. Hile eylemi ise hileyi gerçekleştirenin kendi menfaati lehinde aldatma yoluyla kıymeti olan bir şeyi elde etmesi veya bir yükümlülükten kaçınmasını içeren faaliyetlerdir (Hacıhasanoğlu ve Karaca, 2015: 118).

İç Denetçiler Enstitüsü (Institute of Internal Auditors-IIA), Amerikan Sertifikalı Kamu Muhasebecileri Enstitüsü (American Institute of Certified Public AccountantsAICPA) ve ABD Hile Araştırmacıları Birliği (Association of Certified Fraud Examiners-ACFE) hile eylemini, "başkalarını aldatmak için bir kazanç elde etmek veya bir kaybı telafi etmekle sonuçlanan kasti fiillerdir" şeklinde ifade etmişlerdir (Varıc1, 2012: 15).

Hile, gizleme veya güven ihlali biçiminde tanımlanabilecek, kanunlara aykırı bir eylemdir. Hile eyleminde şiddet veya güç kullanımı söz konusu olmayıp kurumlar veya şahıslar tarafından gerçekleştirilebilir. İşletmeye yönelik yapılan hile eylemleri, tüm dünyayı ilgilendiren bir sorun haline gelebilmektedir. İşletmelerde gerçekleştirilen hileli işlemlerin sıklığı da tutarı da gün geçtikçe artmaktadır (Bozkurt, 2009: 4).

Hile eyleminin tek bir tanımı bulunmamaktadır. Ancak tanımlardan hareketle genel bir kanıya ulaşabilmek mümkündür. $\mathrm{Bu}$ açıdan hile eylemi; işletme yönetimi ile yönetimden sorumlu kişilerin, çalışanların veya üçüncü şahısların kişi ve kurumları kasıtlı olarak kandırarak ya da aldatarak haksız kazanç elde etme eylemi olarak ifade edilebilir (Çetin,2018: 4752).

İnsanı hile yapmaya yönelten birden fazla dürtü (sebep, saik) vardır ve bunları sınırlamak doğru değildir. Hile yapma eylemi bu dürtülerin uygun zamanda uyanması ile olur. Donald R. Cressey tarafindan 1940'ların sonlarında geliştirilen hile üçgeni ${ }^{1}$ teorisine göre; hileden söz edilmesi için baskı, firsat ve haklı gösterme olarak adlandırılan üç durumdan en az birinin var olması gerekir. Hile üçgeni yaklaşımına ek olarak Wolfe ve Hermenson, kişinin hile yapmadaki yeteneğini, diğer bir ifade ile hileyi gerçekleştirebilmeye yetebilecek bilgi ve beceriye sahip olması özelliğini dördüncü bir unsur olarak hile üçgenine eklemiştir. Kişileri hile yapmaya iten unsurların değerlendirilmesinde yetkinliklerin dikkate alınması hile üçgenini, hile karosuna dönüştürmüştür (Doğan ve Kayakıran 2017: 173).

\footnotetext{
1 Donald.R.Cressey'in çalışmalarında "hile üçgeni" terim olarak hiç geçmemektedir. "Hile Üçgeni”ni bir terim olarak ortaya koyan kişi
}

\section{Hile Eylemini Gerçekleştirenlerin Karakteristik Özellikleri}

Hile eylemini gerçekleştiren işletme çalışanlarının aşağıdaki karakteristik özellikleri taşıdıkları saptanmıştır (ACFE, 2018; Çetin, 2018: 4756):

> Hilekârlar risk alma eğilimlidirler ve risk almaktan kaçınmamaktadırlar.

$>$ Hile yapan erkekler toplam hile yapanların \%70'den fazlasını oluşturmaktadır. $\mathrm{Bu}$ oran erkeklerin kadınlara oranla daha çok hile yaptıklarını ortaya koymuştur.

> İşletme çalışanlarından her yaş grubunun hileye karıştığı, hile yapanların ileri yaşlarda oldukları görülmüştür ve en çok hile yapan grubun 40-50 yaş aralığındaki grup olduğu tespit edilmiştir. Çünkü bu yaş grubundaki kişiler işletmede üst düzeylerde olup belirli yetkileri elde etmiştir.

$>$ Evlilerin bekârlara göre daha fazla hile yaptıkları ve mutlu evlilikleri olduğu görülmüştür.

> Hilekârların \%50'ye yakınını üniversite mezunları ile lise mezunları oluşturmasına rağmen parasal açıdan en büyük zarar lisansüstü seviyede eğitim almış kişilerden gelmektedir.

$>$ Hilekârların zeki olduğu ya da bu iddiada bulundukları raporlanmıştır. Kendilerini zeki sanan bu kişiler, sisteme meydan okumak adına hile yoluna gitmektedirler.

> Kuralları ihlal etme eğiliminde olanların hile yapmaya daha meyilli olduğu tespit edilmiştir. Ayrıca bu kişilerin işle ilgili aşırı meraklı ve oldukça azimli oldukları, dolayısıyla da ilgi düzeylerinin çok yüksek olduğu gözlemlenmiştir.

$>$ Hilekârların stresli, sinirli ve sorunlu oldukları belirlenmiştir. Ayrıca kumar, içki ve uyuşturucu gibi kötü alışkanlıklarının da olduğu görülmüştür.

> Hilekârlar egoist yapıda olup ve kendilerini diğer çalışanlardan daha önemli biri gibi görme eğilimindedirler. Üstlerine ve diğer çalışanlara karşı küçümseyici bir şekilde davranmaktadırlar.

> Hilekârların işte geç saatlere kadar vakit harcamakta oldukları ve tatile çıkmaktan kaçındıkları görülmektedir. Bunun yanında rahat bir yaşam, pahalı hobiler, bol para harcama tutkusu hile eğilimini artıran göstergelerdir. Ayrıca çalışanın hayat standartlarının sebepsiz olarak yükselmesi hile fiilinin habercisi olabilmektedir.

\section{Hile Eylemine Psikolojik ve Ekonomik Açılardan Bir Bakış}

Hile eyleminin gerçekleşmesine sebep olan psikolojik ve ekonomik faktörler aşağıda başlıklar halinde yer almaktadır.

\subsection{Psikolojik Açıdan Hile Eylemi}

Psikoloji, Latince "Psihe" yani ruh ve "Logos" yani bilgi kelimelerinin birleşmesiyle oluşan bir kelimedir. Dilimize tercüme edildiğinde "Ruh Bilim" ifadesini karşılamaktadır (Erem, 2003: 11).

Psikoloji, gözlenebilen olayları ele alarak bu olaylar içerisindeki ilişkileri çözümleyerek sınıflandırmaktadır.

ACFE'nin de kurucusu olan ve hile konusunda çok sayıda çalışmalar yapan Joseph T. Wells'dir (Tarhan Mengi, 2012:116). 
Psikoloji, insanın çevresindeki canlı ve cansız varlıkları, olayları nasıl anladığını, nasıl öğrendiğini ve düşündüğünü, nasıl heyecanlandığını, duygularını nasıl gösterdiğini, kişilerin zekâsını ve kişiliğini araştırır. Bu açıklamaya göre, "Psikoloji, insan ve hayvan davranışlarını inceleyen bir bilimdir" şeklinde genel kabul görmüş bir tanım yapılabilir. Diğer bir psikoloji tanım ise, zihinsel süreçlerin ve davranışların sistematik ve bilimsel olarak analiz edilmesidir (Aydin, 2017: 93).

İlk bakışta hile eylemi psikolojik açıdan açgözlülük ve sahtekârlık sözcükleri ile eşleştirilmektedir. Fakat hile eylemini psikolojik açıdan sadece bu iki kelimeyle bütünleştirmek doğru olmamaktadır. Nitekim kanunlara uygun davranan ama açgözlü birçok kişi olabilir veya her dürüst olmayan insanın hile yapacağı düşünülemez. Günümüze kadar davranış uzmanları bir kişinin psikolojik karakterinin hile eylemine yetkin olup olmadığını belirleyen geçerli bir kanıt bulamamışlardır.(Jafarova, 2009: 70).

Psikolojinin hile ilgili alt kategorileri şöyledir:

Suç Psikolojisi: Türk Dil Kurumu'na göre suç, ahlaka ve yasalara aykırı davranışlar olarak tanımlanmaktadır. Suç psikolojisi ise, suçluların suçu işlemeden önce, suçu işleme aşamasında ve suç sonrasını da kapsayan süreçteki bütün davranışlarının incelendiği psikoloji alanıdır (Şentürk, 2017:150). Suç psikolojisi, suçun kaynağını bireyde arar ve suçu normal bir durum olmaktan çok kişide var olan ve öğrenilen anormalliklerin bir sonucu olarak görür. Bu açıdan bakıldığında suç eylemleri, yalnız bir davranışın veya kişisel bir özelliğin sonucu olmaktan ziyade bir sürecin parçasıdır.

Suç çeşitlerinde davetlerde çantasını açık bırakan bir mağdurun hırsızlığa uğraması, yüksek oranda alkol kullanan bir kişinin iradesizliği sonucu araba kazası geçirmesi ve açöozlülüğü sebebiyle hile eylemine kalkışan hilekârın yaptıkları örnek verilebilmektedir.

Adalet Psikolojisi: Adli psikoloji; psikolojinin kuramsal ve pratik bilgisinin kanunların uygulanması ve adaletin sağlanması için kullanımının amaçlanması sonucunda oluşan psikolojinin bir uzmanlık alanıdır (Akdaş ve Oral, 2006: 72).

Adalet psikolojisinin içerisinde incelenen konular tamamen suç ve suçluya ilişkin ayrıntılı inceleme yapılmasını sağlayan konulardır. Bu konuların bazıları; suça ilişkin yaklaşımlar, kriminal kişilikler ve psikopatoloji, sorgu teknikleri, görgü tanı̆̆ı ifadelerinin değerlendirilmesine ilişkin teknikler, psikolojik profilleme, kurban ve mağdurların psikolojik açıdan incelenmesi, ayrımcılık, cinsel taciz ve tecavüzlerin araştırılması, etik ikilemler, adalet ve ahlaka yönelik algılama sistemi, mahkeme sürecinde davranışların incelenmesi, 1slah ve rehabilitasyona yönelik çalışmalar şeklindedir. Adalet psikolojisinin incelediği konulardan anlaşılacağı gibi adalet psikolojisi genel hukuksal alanlarda kullanılabilmektedir. Konular hile, hile denetimi ve hilekâr profilleme açısından da büyük fayda sağlayabilecek verilere ulaşılmasına yardımcı olacağını göstermektedir (Aydın, 2017: 104).

Ekonomik Psikoloji: Uluslararası Ekonomik Psikoloji Araştırmaları Birliği ekonomik psikolojiyi, "tüketim ve diğer ekonomik davranışları içeren psikolojik mekanizmalar ve süreçleri kapsayan bir disiplindir" şeklinde tanımlamaktadır. Ekonomik psikoloji genel itibariyle tercihler, seçimler, kararlar ve bunu etkileyen faktörler, aynı zamanda ihtiyaçların tatminiyle ilgili karar ve seçimlerle uğraşmaktadır (Otto, 2009: 16).

Ekonomik psikoloji, ülkedeki ekonomik davranışların gözlenmesiyle başlar. Bu ekonomi alanı, aynı uyarıcılara farklı zamanlarda ve durumlarda farklı tepkilerin verilmesiyle ortaya çıkar. Geleneksel ekonomistler piyasa davranışlarını izleyerek gelir, fiyat, harcanan tutar, yatırım ve tasarrufların birbirleriyle olan ilişkilerini incelerken davranışsal ekonomistler, insanların beklentilerini, tutum ve davranışlarını etkileyen psikolojik faktörlerin yatırım, tasarruf ve harcama eğilimleri üzerindeki etkilerini analiz ederler (Katona and Harris, 1978: 14). Ekonomik psikoloji, akademik çevrelerde "davranışsal finans" olarak da adlandırılmaktadır.

Ekonomik psikoloji, karar verme sürecine etki eden davranışsal faktörlerin analiz edilmesini amaçlamaktadır. $\mathrm{Bu}$ ekonomi dalının temelini bireysel yatırımcilar ve bu yatırımcıların almış oldukları kararlar oluşturmaktadır. Bireysel yatırımcıların gerek uzun vadeli gerekse kısa vadeli yatırım kararları sermaye piyasalarının vazgeçilmez unsurlarındandır. Sermaye piyasası araçları bireysel yatırımcıların varlığıyla bir anlam taşımaktadır. Bireysel yatırımcıların ilgilenmediği piyasalar sağlıklı bir şekilde gelişmez. Bu durum ise ekonomik verimliliği azaltır (Barak, 2008: 31).

İnsanlar içerisinde bulundukları ruh durumlarına ve ekonomik ortama göre üretimlerini azaltmakta ya da arttırmaktadır. Borsada panik dönemleri, enflasyonla mücadele, spekülasyonlar, iyimser havayla düzelen ekonomik durum ekonomi ve psikoloji arasındaki etkinin ipuçlarını verir. Çağımızda ekonominin sadece finansal faaliyetler olarak değil aynı zamanda karşılaşılan sorunlar veya güven ortamı ile doğru orantılı olduğu unutulmamalidir.

Ekonomik piyasalardaki durumlar nasıl finansal anlamdaki kazançları etkiliyorsa kötü gidişat da insan davranışlarını etkilemektedir. İnsanların ruh halleri yatırım yaptıkları, beklenti içine girdikleri maddi kazanımların ters yönde oluştuğunu görünce çöküşe uğramaktadır. Bu çöküşler, kazancını kaybeden insanların kaybettiklerini hileyle, dolandırıcılıkla geri alma çabasına girmelerini tetikleyecek, hile üçgeninde var olan baskı unsurunu oluşturacaktır (Aydın, 2007: 109).

Çalışma Psikolojisi: Genel olarak çalışma psikolojisi, psikoloji biliminin bir alt dalı olarak nitelendirilebilecek uygulamalı psikolojinin işyeri ve örgüt düzeyindeki uygulaması olarak değerlendirilebilir.

Arnold ve diğerleri (2005) uygulamalı psikoloji geleneği içinde çalışma psikolojisinin iki ana araştırma alanından bahsetmektedir. Bunlardan ilki, "birey iş uyumu" ana düşüncesi altında, "bireyin işe uyması" ve "işin bireye uyması" geleneklerini yansitmakta iken, ikincisinin ilgilendiği konu "beşeri ilişkiler" geleneğidir. Bunlardan kısaca bahsetmek gerekirse; bireyin işe uyması geleneği altında, personel seçimi, eğitim ve mesleki danışmanlık konuları ön plana çıkmakta, bireye odaklanılarak, birey ile iş arasında etkin bir uyum sağlanmaya çalışılmaktadır. Diğer yandan, işin bireye uyumunda, işin öne çıkarılıp, görevlerin, ekipmanların ve çalışma koşullarının bireyin fiziksel ve psikolojik özelliklerine göre tasarlanması üzerinde 
çalışılmaktadır. Diğer ana araştırma alanı olan beşeri ilişkilerde ise birey, grup, örgüt ve çalışma arasındaki karmaşık etkileşim konu edilmektedir. Birey ve iş uyumu geleneklerinden farklı olarak, burada çalışma yaşamındaki sosyal faktörler vurgulanmaktadır (Arnold vd., 2005: 17-18).

İş dünyasında çalışan çalışma psikologlarının çalışanlarla devamlı iletişim halinde olması, onların sorunlarını çözme odaklı yaklaşımları, psikolojik açıdan düşüş yaşamalarının önlenmesi gibi konularda oldukça önemlidir. Hile eylemi çoğunlukla işten ve yöneticilerden sıkılmış, haksızlığa uğradığını düşünen, kendini işle bağdaştıramayan kişilerce gerçekleştirilen bir eylemdir. Çalışma psikologları bu eylemleri yapan kişilere destek olma ve olası hileleri önlemek üzere iş yapan kişi veya birimlerdir.

\subsection{Ekonomik Açıdan Hileli Eylemi}

21.yy'da Enron, Worldcom, Parmalat gibi büyük işletmelerin ve özellikle de farklı yatırım bankalarının sebep olduğu finansal skandallar ülke ekonomilerinin sarsılmasına hatta ekonomik Krizlerin ortaya çıkmasına ya da (meydana gelmesine) sebep olmuştur. Bu skandalların temelinde ise hile eylemi vardır.

Hile eylemleri, yüksek meblağlarda zararlara sebep olabilmektedir. Özellikle de işletmelerin mali tabloları üzerinde yapılan hileli işlemler yanlış ve yanıltıcı bilgi vererek ekonomik gelişmeyi olumsuz etkileyip, yatırımcılara da zarar vermektedir. Mali tablolarda yapılan hileli işlemler şirketlerin birbiriyle karşılaştırılmalarına imkân vermemekte bu durum şeffaflığ 1 azaltmakta, sermaye piyasalarının etkin bir şekilde çalışmasını durdurmakta bu durumların varlığ ekonomik büyümenin hızını düşürmektedir. Oysaki para ve sermaye piyasalarının etkin bir şekilde çalışabilmesi için, yatırımcıların ve borç verenlerin doğru ve güvenilir finansal tablolara ulaşması gerekmektedir. Nitekim yatırımcılar bu finansal tablolardan aldıkları doğru ve güvenilir bilgi neticesinde yatırım kararını vermektedir. Açıklamalardan da anlaşılacağı üzere işletmelerin sunduğu finansal raporlara en çok yatırımcılar ihtiyaç duymaktadır. Zira yatırımcılar işletmelerin yayınladıkları finansal tablolardaki bilgi ve raporlara göre yatırım yapmaktadırlar. Bu bilgiler sayesinde kazanç sağlamaktadırlar. Dolayısıyla yatırımcıların kazançlarının artması toplumun refah artışına da fayda sağlamaktadır. $\mathrm{Bu}$ sebeple finansal tablolarda yapılacak herhangi bir hile sadece yatırımcıları değil aynı zamanda ülke ekonomilerini de zarara uğratacaktır (Demir ve Bahadır 2007: 7). Nitekim ACFE'nin 2016 Hile Raporuna göre hile yoluyla gerçekleşen kayıpların (ABD \$ cinsinden) ortalaması 150 bin dolardır. Buna ek olarak ACFE'nin Hile Raporu'nda yer alan bazı önemli tespitler şunlardır (ACFE, 2016: 4).

$>$ İşletmeler varlıklarının ortalama \%5'ni hileli işlemlerden dolayı kaybetmektedirler. Bu sonuçtan yola çıkarak dünyanın Gayri Safi Milli Hasılasının 3,7 trilyon dolarının hileli işlemlerden dolayı kaybedildiği söylenebilir.

> Araştırma sonuçlarına göre hileli işlemlerden dolayı işletmelerin ortalama kayıpları 150 bin dolardır,

> Hileli işlemlerden dolayı mağdur kuruluşların \%58'i kayıplarının hiç birini telafi edemezken, sadece \%14'ü kayıplarını telafi edebilmiştir. Raporda yer alan hile vakalarının \%8,4'ü cezalandırılmıștır.
$>$ Hileden en çok zarar gören sektör; bankacılık, mali hizmetler, imalat endüstrisi ve devlet (kamu) olarak tespit edilmiştir.

Hilelerin ekonomik açıdan olumsuz sonuçlarını aşağıdaki gibi özetlemek mümkündür (Kandemir, 2010: 15).

> Finansal tablo kullanıcılarının, sermaye piyasalarına güvenini azaltmaktadır.

$>$ Hileli finansal raporlama mali tabloların bağımsızlığını ve tarafsızlığını azalttığı için, sermaye piyasalarının etkili ve verimli çalışmasını engellemekte bu durum da ekonomik büyümenin hızını düşürmektedir.

> Yargılama giderlerin büyük meblağlara ulaşmasına yol açmaktadır.

$>$ Hile olaylarına karışan bireylerin meslek yaşantılarını sona erdirmektedir. İşsizlik oranı yükselmektedir.

$>$ Hileye maruz kalan işletmenin iflas etmesine veya telafisi zor olan ekonomik kayıplara yol açmaktadır.

\section{Muhasebe Meslek Mensubunu Hile Eylemine Yönelten Psikolojik ve Ekonomik Faktörler}

Muhasebecilik mesleğinde meslek elemanını hileli işlem yapmaya iten/zorlayan psikolojik ve ekonomik temelli olmak üzere çeşitli faktörler vardır. Psikolojik ve ekonomik faktörlerden en önemli görülenleri, literatürden yararlanılmak suretiyle alt başlıklar halinde aşağıda sunulmuştur. Ancak gerçek olan şu ki bir baskı türü diğer baskı türleriyle çok yakından ilgilidir.

\subsection{Psikolojik Faktörler}

Literatürde, muhasebe meslek mensupları üzerinde hile olgusunun doğrudan psikolojik açılardan incelendiği bir çalışmaya rastlanmamıştır. Ancak meslek elamanının mesleki faaliyetlerinde karşılaştığı sorunları psikolojik yönden saptamaya çalışan ifadelerin yer aldığı çalışmalar mevcuttur. $\mathrm{Bu}$ çalışmalar incelenmek suretiyle meslek elamanını hileli işlem yapmaya yönelten faktörler başlıkla halinde sunulmaya çalışılmıştır.

\subsubsection{Mükellef Baskısı Yaşamak}

Yapılan birçok çalışmada, meslek elemanlarının, mükellef baskısını yoğun olarak yaşadıkları ortaya konulmuştur. Mesela, "Muhasebe Meslek Ahlâkı, Etik ve Müşteri Tatmini İlişkisi” adlı bir çalışmada (Kaya ve Yanık, 2011: 303), Erzurum ilindeki meslek mensuplarına "meslek mensuplarını sizce etik dışı davranışlara iten faktörler nelerdir?" sorusu yöneltilmiştir. Meslek mensuplarının "mükellefler, kanunlar, kredi kuruluşları, meslek odaları, meslek üyeleri" seçeneklerinden \%59 oranla "mükellefler" seçeneğini seçtikleri bulgusuna ulaşılmıştır. Başka çalışmalarda da (Aymankuy ve Sarıoğlan, 2005: 43; Kaya, 2016: 192; Özyürek, 2012: 1341; Gür, 2018: 388) meslek mensuplarını etik dışı davranışlara iten faktörler arasında meslek mensuplarının "mükellefler" seçeneğine daha çok katılım gösterdikleri saptanmıştır.

Mükellef baskısının şekli ve niteliği çok farklılık gösterebilmekte, bu baskı kendisini çok farklı alanlarda hissettirmektedir. Örneğin, Afyonkarahisar ilinde muhasebe meslek mensupları üzerinde yapılmış bir çalışmada (Kirik, 2007: 60-65), muhasebe işlemlerinin kayıtlara geçirilmesi sırasında mükellefler tarafından yapılan baskıların, meslek 
mensuplarını güç durumda bıraktı̆̆ı, meslek mensuplarının kamu menfaatleri ile mükellef menfaatleri arasında kaldıkları tespit edilmiştir. Başka çalışmalarda da (Yıldız, 2010: 169-170; Gümüş vd., 2016:26; İşü̈den ve Çabuk, 2006: 76-77) meslek mensuplarının büyük çoğunluğunun bu sonucu destekledikleri ve bu yöndeki ifadelere olumlu katılım gösterdikleri saptanmıştır.

\subsubsection{Müşteri Kaybetme Korkusu Yaşamak}

Meslek mensuplarının müşteri kaybetme kaygısıyla da hileli işlemlere başvurma durumu söz konusu olabilmektedir. Hileli işleme başvuran meslek mensubu etik çelişkilere girebilmektedir. Özellikle de mükelleflerin vergiyi kaçırma girişimleri kamu menfaatini de ilgilendirdiği için meslek mensubu bunun ahlaki ve vicdani sıkıntısını daha da çok yaşamaktadır. Yapılan birçok çalışma sonuçları da bu durumu destekler niteliktedir. Örneğin bir araştırmada (Yel, 2018: 94), Bolu ilinde faaliyet gösteren muhasebe meslek mensuplarına "müşteriyi kaybetme kaygısıyla yasal olmayan müşteri tekliflerini uygulayan meslektaşlar vardır" ifadesi yöneltilmiş, meslek mensuplarının yarıdan fazlasının bu ifadeye olumlu yönde katılım gösterdiği saptanmıştır. Sivas ilinde yapılmış bir çalışmada (Kısakürek ve Alpan, 2010: 221-223), aynı yöndeki ifadeye meslek mensuplarının \%51'inin olumlu katılım gösterdiği bulgusuna ulaşılmıştır.

Müşteri kaybetme korkusu yaşamak, meslek elemanını hileli işlem yapmaya yönelten psikolojik faktörler arasında görünse de ekonomik faktörü de bünyesinde barındırmaktadır. Nitekim müşteri kaybetme korkusu yaşayan dolayısıly da ekonomik bir kaygl ile hareket eden meslek mensubu mesela ücret tarifesinin altında çalışmakta veya yasal olmayan talepleri yerine getirme eğiliminde olabilir.

\subsubsection{Meslektaşların Yanlış Uygulamaları}

Meslektaşların, mesleğin icrasında yaptıkları yanlış veya hileli uygulamalar dürüst meslek mensubunu etkilemektedir. Örneğin, Isparta ilinde muhasebe meslek mensupları üzerinde yapılan bir çalışmada (Çetin ve Dağlı, 2014: 7071), meslek mensuplarının "meslek mensubu arkadaşlarımdan etik hareketlerde bulunmadığını düşündüğüm kişiler var" ifadesine $\% 49,6$ oranında olumlu yönde katılım gösterdikleri tespit edilmiştir. Ankara ilinde yapılan bir çalışmada da (Özyürek, 2012: 134), meslek mensuplarına "bazı meslek mensuplarının gerçekleştirdiği kişisel suiistimaller mesleğin saygınlığını azaltmaktadır" ifadesi yöneltilmiş, meslek mensuplarının \% 52'inin olumlu yönde katılım gösterdiği tespit edilmiştir. Erzurum ilinde yapılan bir çalışmada (Güney ve Çınar, 2012: 99-103) ise, meslek mensuplarına "meslek mensupları, mükellefleri ile ilgili bilgileri, ilgisi olmayan başka şahıslara açıklamaktadırlar" ifadesi yöneltilmiş meslek mensuplarının tamamına yakınının $(\bar{X}=4,049)$ bu ifadeye kesinlikle katılıyorum düzeyinde katılım gösterdiği tespit edilmiştir. Yine meslek mensuplarına "meslektaşlarımın vergi ahlakına aykırı tutumları beni de muhasebe etiğine aykırı davranışlara zorlamaktadır" ifadesi yöneltilmiş, meslek mensuplarının yarıdan fazlası bu ifadeye olumlu yönde katılım göstermiştir (Yücel, 2017: 241). Sivas ilinde yapılmış bir çalışmada da (Kısakürek ve Alpan, 2010: 221-223), meslek mensuplarını etik dışı davranışa iten sebepler araştırılmış ve araştırma sonucunda meslek mensuplarının, "meslek mensubunun daha fazla para kazanma tutkusu" ifadesine \%96 oranında katılım gösterdikleri saptanmıştır.

\subsubsection{Mali Tabloların Manipüle Edilmesi Talebiyle Karşılaşmak}

Mükellefler, işletmeyle ilgili çeşitli amaçların gerçekleşmesi için muhasebecilerinden mali tablolar üzerinde bir takım manipülatif işlemlerin yapılmasını talep edebilmektedirler. Örnekler vermek gerekirse, Afyonkarahisar ilinde muhasebe meslek mensupları üzerinde yapılmış bir çalışmada (Kirik, 2007: 60-65), meslek mensuplarının mükelleflerin bilanço maskelemesi isteğine \%49; kârın yüksek gösterilmesini isteğine $\% 52$ ve giderlerin artırılması veya gelirlerin azaltılması suretiyle vergi matrahının düşürülmesi isteğine \%59 oranında katılım gösterdikleri saptanmıştır. Aydın ilindeki meslek mensupları üzerinde yapılan bir başka araştırmada da (Gümüş vd., 2016:26) bu yöndeki ifadelere katılım yüksek olmuştur. "Muhasebe Hata ve Hileleri: Meslek Mensupları Üzerine Bir Araştırma" adlı çalışmada (Özçelik vd., 2017: 209-210), Batı Akdeniz Bölgesi'nde faaliyet gösteren meslek mensuplarına "mükelleflerden bilanço kârını düşük gösterilmesi talepleri ile karşılaştım" ifadesi yöneltilmiş, meslek mensuplarının tamamının bu ifadeye katıliyorum yönünde görüş bildirdikleri saptanmıştır. Diyarbakır ilinde yapılan "Muhasebe Hata Ve Hilelerinin Meslek Etiği Açısından İrdelenmesi” adlı bir çalışmada (Okay, 2011: 93-94), meslek mensuplarına "bilançoda işletmenin aktif hesaplarının olduğundan daha iyi gösterilmesinin en büyük nedeni nedir?" sorusu yöneltilmiş seçeneklerden "kredi kuruluşlarında daha fazla kredi almak" ifadesine meslek mensuplarının \% 98,8'inin olumlu yönde katılım gösterdiği tespit edilmiştir. Yine aynı çalışmada meslek mensuplarına "bilançoda işletmenin aktif hesaplarının olduğundan daha kötü gösterilmesinin en büyük nedeni nedir?" sorusu yönetilmiş meslek mensuplarının tamamı "daha az vergi ödemek" seçeneğini işaretlemişlerdir.

Mali tabloların manipüle edilmesi talebiyle karşılaşmak, meslek elemanını hileli işlem yapmaya yönelten psikolojik faktör gibi görünse de ekonomik faktörü de bünyesinde barındırmaktadır. Zira meslek mensubu mükelleften gelen bu talebi müssteri kaybetme riskini yaşamamak için ekonomik kaygı ile kabul ettiğinde psikolojik olarak da etkilenecektir.

\subsection{Ekonomik Faktörler}

Literatürde muhasebe meslek mensupları üzerinde hile olgusunun ekonomik açılardan inceleyen doğrudan bir çalışmaya rastlanmamıştır. Ancak bu konulara değinen ifadelerin yer aldığ incelenmek suretiyle meslek elamanını hileli işlem yapmaya yönelten faktörler başlıkla halinde sunulmaya çalışılmıştır. Ekonomik faktörlerin psikolojik faktörlerle içi içe olduğu gerçeği de unutulmamalıdır.

\subsubsection{Daha Az Vergi Ödetilmesi Talebiyle Karşılaşmak}

Meslek mensuplarını mesleki anlamda hileli davranışa iten faktörlerin başında mükelleflerin vergisel konularda yapmış oldukları baskılar gelmektedir. Mükellefler meslek mensuplarından kârı düşük göstererek vergiyi azaltmalarını isteyebilmektedirler. Yapılan çalışmalar göstermektedir ki bu yöndeki baskılar ülke genelinde mevcuttur. Nitekim Doğu Karadeniz Bölgesinde faaliyette bulunan meslek 
mensupları üzerinde yapılan çalışmada (Daştan, 2011: 196), meslek mensuplarına "muhasebe meslek mensuplarının vergisel konularda baskı ya da telkin alıp almadıkları durumu" sorulmuş ankete katılanların \% 59'u bu ifadeye olumlu yönde katılım göstermiştir. Adana ilinde yapılan bir araştırmada (Organ ve Yeğen, 2013: 261-262), aynı yöndeki ifadeye meslek mensuplarının büyük çoğunluğunun $(\bar{X}=$ 3,52) "katılıyorum" düzeyinde görüş bildirdikleri tespit edilmiştir. Yalova ve Bilecik ilinde yapılan bir başka çalışmada (Gökgöz ve Zeytin, 2012: 483-484), aynı türden ifadeye meslek mensuplarının \%34'ünün olumlu katılım gösterdiği bulgusuna ulaşılmıştır. Yine Adana ilinde yapılan başka bir çalışmada (Organ ve Yeğen, 2013: 261-262) "Tanıdığım bazı meslek mensupları mesleki hayatlarında vergi kaçırma konusunda etik ikilem yaşamaktadırlar" ifadesi yöneltilmiş, meslek mensuplarının çoğunluğunun $(\bar{X}=3,50)$ bu ifadeye "katıllyorum" düzeyinde görüş bildirdikleri saptanmıştır.

"Muhasebe Meslek Mensuplarının Etik Dışı Davranışlarının Vergi Ahlakına Etkisi” adlı çalışmada (Yücel, 2017: 241), Bursa ilindeki meslek mensupları "mükellefler muhasebe meslek mensuplarını az vergi ödemek için zorlamaktadırlar" ifadesine, \% 57,2 oranında katıldığı bulgusuna ulaşılmıştır. İstanbul ili Kartal ilçesinde yapılan bir çalışmada da (Korucu, 2018: 61), meslek mensuplarının \%80'nin müşterilerinin vergi ödememek adına kendilerini hileye yönlendirdiklerine katılım gösterdikleri saptanmıştır.

Daha az vergi ödetilmesi talebiyle karşılaşmak, meslek elemanını hileli işlem yapmaya yönelten ekonomik faktör gibi görünse de psikolojik faktörü de bünyesinde barındırmaktadır. Nitekim daha az vergi ödetilmesi talebinin reddi halinde müş̧teri kaybını yaşayacağını düşünen bir meslek elemanı hem ekonomik hem de psikolojik açılardan sorunlarla karşılaşabilecektir.

\subsubsection{Asgari Ücret Tarifesinin Altında Hizmet Vermeye Zorlanmak}

Meslek mensuplarının en çok karşılaştıkları problemlerden birisi mükelleflerin baskılarıyla ücret tarifesinin altında çalışmalarıdır. Ücret tarifesinin altında çalışan meslek mensupları meslektaşlarını da bu yönde çalışmaya bir yerde mecbur bırakmaktadır. Ücret tarifesinin altında çalışmaya mecbur kalan meslek mensubu hem mükelleflerinin hem de mükellef baskısıyla ücret tarifesini değiştiren meslektaşlarının baskısı altında kalabilmektedir. Bu türden baskıların varlığını destekleyen çok çalışma vardır: Yapılan bir araştırmada (İşgüden ve Çabuk, 2006: 76-77), Balıkesir ilinde faaliyetlerini sürdüren meslek mensuplarına "meslek mensupları, müşterilerinin baskısı sebebiyle, ücret tarifesinin dışına çıkmaktadırlar" ifadesi yöneltilmiş; meslek mensuplarının \% 76,7'si bu ifadeye olumlu yönde katılım göstermiştir. Bingöl ilinde yapılan başka bir çalışmada da (Gür, 2018: 388) bu yöndeki ifadeye meslek mensuplarının yaklaşık \% 47'sinin olumlu yönde katılım gösterdiği saptanmıştır. Yalova ve Bilecik ilinde faaliyette bulunan meslek mensuplarının mesleki faaliyetlerinde karşılaştıkları sorunlarını ve beklentilerini tespit etmeyi amaçlayan bir çalışmada (Gökgöz ve Zeytin, 2012: 483-484), meslek mensupları "alınan ücretlerin emeğimizin karşılığının çok altındadır" ifadesine \% 66 oranında; "mükelleflerden muhasebe ücretlerinin zamanında veya hiç tahsil edilememesi durumunu yaşıyorum" ifadesine ise \% 55 oranında olumlu yönde katılım göstermişlerdir. Yine bir başka çalışmada (K1sakürek ve Alpan, 2010: 221-223), meslek mensuplarına "müşteriyi kaybetme kaygısıyla tarifenin altında ücret alan meslektaşlar vardır" ifadesi yöneltilmiş meslek mensuplarının \%73'ünün olumlu yönde katılım gösterdiği tespit edilmiştir. Soylu'nun ( 2018: 85-86) çalışmasında da bu yöndeki ifadelere katılım yüksek olmuştur.

Asgari ücret tarifesinin altında hizmet vermeye zorlanmak, meslek elemanını hileli işlem yapmaya iten/zorlayan psikolojik faktör gibi görünse de ekonomik faktörü de bünyesinde barındırmaktadır. Nitekim meslek mensubu müşteri kaybı yaşamamak için tarifenin altında çalışmayı kabul ederek ekonomik bir kaygl gütmektedir. Ayrıca ücret tarifesinin altında çalışmak zorunda kalan meslek mensupları meslektaşlarını da bu yönde çalışmaya bir yerde mecbur birakmaktadır.

\subsubsection{Kayıt dışı Ekonominin Varlığ}

Kayıt dışı ekonominin oluşumuna sebep olan birçok ekonomik faktör mevcuttur. Ekonomik istikrarsızlık, yüksek enflasyon, işsizlik gibi faktörler kayıt dışı ekonominin miktar ve boyutunu artırmaktadır. Özelliklede devletin ekonomik alandaki müdahaleleri, bu müdahaleden kaçmaya çalışan kişileri hile ve yolsuzluğa sürüklemektedir. Nitekim Kayseri'de faaliyet gösteren muhasebe meslek mensupları üzerinde yapılmış bir araştırmada (Yıldız, 2010: 169-170), "kayıt dışı ekonomi ve ekonomik istikrarsızlık meslek etiğine zarar vermektedir" ifadesi yöneltilmiş, meslek mensuplarının büyük çoğunluğunun bu ifadelere katıldığı tespit edilmiştir. Muhasebe Meslek Ahlâkı, Etik ve Müşteri Tatmini İlişkisi" adlı çalışmada ise (Kaya ve Yanık, 2011: 303), meslek mensuplarına "kayıt dışı ekonomiye devletin ve mükelleflerin uygulamaları sebep olmaktadır" ifadesi yöneltilmiş, meslek mensuplarının \% 37,9'nun olumlu yönde katılım gösterdiği tespit edilmiştir.

\subsubsection{Vergi Oranlarının Yüksekliği}

Vergi oranlarının yüksekliği mükelleflerin daha az vergi ödeme isteğiyle çelişmektedir. Bu durumda ise mükellefler, meslek mensuplarına vergiyi az çıkarmaları noktasında baskı yapmaktadırlar. Baskı altında kalan meslek elemanı ise hileli işlemlere yönelebilmektedir. Nitekim Diyarbakır ilinde yapılan "Muhasebe Hata Ve Hilelerinin Meslek Etiği Açısından İrdelenmesi” adlı bir çalışmada (Okay, 2011: 93 94), meslek mensuplarına "vergi uygulamaları ve vergi oranları yapılan hata ve hileler üzerinde etkili midir?" sorusu yöneltilmiş meslek mensuplarının \%56,5'inin olumlu yönde katılım gösterdiği bulgusuna ulaşılmıştır. Aydın ilindeki meslek mensupları üzerinde yapılan bir başka araştırmada ise (Gümüş vd., 2016: 26), meslek mensuplarının \%45'lik bir kısmı da vergi boşluklarından yararlanmaya çalıştığını; \%40'lık kısım ise vergi oranlarının yüksekliği ve enflasyondan dolayı hileye başvurulabileceğini ifade etmişlerdir. İstanbul ilinin Kartal ilçesinde yapılan bir çalışmada da benzer sonuçlar elde edilmiştir (Korucu, 2018: 61).

\section{Sonuç ve Değerlendirme}

Muhasebe, parayla ifade edilen işlem ve olayları kaydeden, siniflandiran, raporlayan, analiz edip yorumlayan ve işletmeyle ilgili taraflara doğru bilgiyi vermeyi amaçlayan bir süreçtir. Muhasebe sisteminin başarısını, üretilen 
bilgilerin doğruluğu ve bu sistemde çalışanların bilgi düzeyi ve ahlaki değerleri oluşturmaktadır. Özellikle muhasebe meslek mensuplarının yapmış veya yapmak zorunda oldukları hileli işlemler meslek ahlakını olumsuz etkilemektedir.

İşletmelerin sahipleri, ortakları, yatırımcıları, hissedarları vb. çevrelerden oluşan işletme bilgi kullanıcıları ekonomik kararlar alırken güvenilir bilgiye gün geçtikçe daha çok ihtiyaç duymaktadırlar. Bu durum ise, muhasebe biliminin önemini artırmaktadır. Meslek mensuplarını hileli davranışa iten psikolojik ve ekonomik birçok faktör bulunmaktadır. Yapılan çalışmalar göstermektedir ki meslek elemanlarını hileli davranışa iten/zorlayan psikolojik ve ekonomik faktörler, ülkenin bir iline veya bir bölgesine özgü olmayıp güneyden kuzeye, doğudan batıya ülkenin bütününe ait bir durum teşkil etmektedir. Dolayısıyla her psikolojik veya ekonomik faktör ülke geneline yaygın bir hale büründüğünden aslında sosyolojik bir nitelik de kazanmaktadır.

Konuyla ilgili literatür incelendiğinde meslek mensuplarını hileye iten/zorlayan psikolojik faktörlerin başında mükelleflerin baskıları gelmektedir. Baskı altında kalan muhasebecilerden bazıları ise müşteriyi kaybetme kaygisıyla, yasal olmayan taleplere uygun hareket edebilmektedirler. $\mathrm{Bu}$ durum ise meslek mensubunun etik çelişkiler yaşamasına yol açabilmektedir. Yine mükellefin baskısı altında kalan ve müşteri kaybetme korkusuyla hareket eden meslek mensubu, ücret tarifesinin dişına çıkabilmektedir. Mükellefler, meslek mensuplarından ya vergiyi az ödemek için kârın düşük gösterilmesini ya da kredi imkânlarını genişletmek için kârın yüksek gösterilmesini istemektedirler. Değişen vergi uygulamaları ve yüksek vergi oranları da meslek mensuplarını hileli işlemlere yöneltebilmektedir.

Yukarıda bahsedilen şartlarda çalışan meslek mensuplarının tükenmişlik düzeyi de beraberinde artmaktadır. Nitekim bu konuda yapılmış birçok çalışma vardır (Dalğar ve Tekşen, 2014; Okutan ve Yıldız, 2013; Türker, 1995; Ay ve Avşaroğlu, 2010).

Muhasebe meslek mensupları, ücret tarifelerinin çok altında çalışmaları; mükelleflerden ücretlerini zamanında veya hiç tahsil edememeleri; ekonomik istikrarsızlık ve kayıt dışı ekonominin varlığı gibi ekonomik durum veya sebeplerden dolayı hileli işleme yönelmekte veya yönelmek zorunda kalabilmektedir.

Meslek mensubunun hileli işlemi gerçekleştirmesinde veya gerçekleştirmek zorunda kalmasında özellikle

> Mükellef baskısı yaşamak,

> Daha az vergi ödetilmesi talebiyle karşılaşmak,

$>$ Asgari ücret tarifesinin altında hizmet vermek, ücreti tahsil edememek,

> Meslektaşların yanlış uygulamaları,

> Müşteri kaybetme korkusu yaşamak,

$>$ Mali tabloların manipüle edilmesi talebiyle karşılaşmak,

$>$ Kayıt dışı ekonominin varlı̆̆l,

$>$ Vergi oranlarının yüksekliği

gibi psikolojik ve ekonomik faktörler etkili olmaktadır.

Literatürden de anlaşılacağı üzere meslek mensupları, başta mükelleflerinin daha sonra da meslektaşlarının oluşturduğu baskı neticesinde tüm çalışma hayatını saran bir baskı döngüsü içerisine girmektedirler. $\mathrm{Bu}$ psikolojik ortam dürüst, meslek etiğini önemseyen meslek mensuplarını da olumsuz etkilemekte ve yapmak istemedikleri davranışları sergilemekle karşı karşıya bırakabilmektedir. Psikolojik baskıyla oluşan bu düşünce meslektaşlar arasında yaygınlaştı̆̆ında sosyolojik bir boyuta evirilecek ve beraberinde ekonomik boyutu da derinden etkileyecektir.

Muhasebe mesleğinde etik kodların en kısa zamanda daha kapsamlı bir şekilde düzenlenerek uluslararası standartlara uygun hale getirilmesi, , vergi oranlarının makul seviyelere çekilerek mükelleflerin vergiyi kaçırma veya daha az vergi ödeme girişimlerinin azaltılması, KGK'nin yayımlamış olduğu "Bağımsız Denetçiler İçin Etik Kurallar" adlı standardın etkin bir biçimde uygulamaya konulması gibi girişimler, mükelleflerin meslek mensuplarını hileli davranışa yönlendirmelerini engelleyebilecektir.

\section{Kaynakça}

Akdaş, A., \& Oral, G. (2006). Akademik Bir Disiplin ve Uygulama Alanı Olarak Adli Psikoloji. Türk Psikoloji Yazllar1, 17(3), 71-90.

Arnold, J.,Randall, R.., \& Patterson, F. (2010). Work Psychology. New York: Financial Times Press.

Association Of Certified Fraud Examiners (2016). Report To The Nation Occupational Fraud \&Abuse. ACFE. USA \& Canada.

Association Of Certified Fraud Examiners (2018). Report To The Nation Occupational Fraud \& Abuse. ACFE. USA \& Canada.

Ay, M., \& Avşaroğlu, S. (2010). Muhasebe Çalışanlarının Mesleki Tükenmişlik, İş Doyumu ve Yaşam Doyumlarının İncelenmesi. Uluslararası İnsan Bilimleri Dergisi, 7(1), 1170-1189.

Aydın, R. (2017). Hile Denetiminin Psikoloji ve Beden Dili Açısından Değerlendirilmesi ve Bir Anket Çalışması. Yüksek Lisans Tezi. İstanbul: Marmara Üniversitesi.

Aymankuy, Y., \& Mehmet S. (2005). Muhasebe Meslek Mensuplarının Meslek Etiğine Yaklaşımları ve Balıkesir İl Merkezinde Bir Uygulama. Balıkesir Üniversitesi Sosyal Bilimler Enstitüsü Dergisi. 8(14), 23-46.

Barak, Osman (2008), Davranışsal Finans. Ankara: Gazi Kitapevi Yayınları.

Çetin, A. C., \& Dağlı, S.Ş. (2014). Muhasebe Meslek Etiği Ve Meslek Mensuplarının Etik Hakkındaki Görüşleri Üzerine Isparta İlinde Bir Araştırma. Süleyman Demirel Üniversitesi Sosyal Bilimler Dergisi. 2 (20), 55-84.

Çetin, H. (2018). Çalışan Hileleri Ve Hile Yapan Çalışanların Karakteristik Özellikleri”, Social Sciences Studies Journal (Sssjournal), 4(23), 47514757.

Dalğar, H., \& Tekşen, Ö. (2014). Muhasebecilerin Mesleki Tükenmişlik Düzeyleri İle Rol Çelişkisi Arasındaki 
İlişkiyi Belirlemeye Yönelik Bir Araştırma. Muhasebe ve Finansman Dergisi, 62, 37- 54.

Daştan, A. (2011). Muhasebe Meslek Mensuplarının Vergi Kayıp Ve Kaçaklarının Önlenmesindeki Rolü: Doğu Karadeniz Bölgesine Yönelik Bir Araştırma. Atatürk Üniversitesi İktisadi ve İdari Bilimler Dergisi, 25( 2), 181-206.

Erem, F. (2003). Adalet Psikolojisi. Ankara: Başkent Klişe Matbaacilik.

Gökgöz, A., \& Zeytin, M. ( 2012). Muhasebe Meslek Mensuplarının Mesleki Faaliyetlerinde Karşılaştıkları Sorunlar ve Beklentileri: Bilecik Ve Yalova İlleri Uygulaması. Süleyman Demirel Üniversitesi Íktisadi ve İdari Bilimler Fakültesi Dergisi, 17(1), 477-493.

Gümüş, U.T., \& Göğebakan, H.(2016). Muhasebe Hata ve Hileleri İle Muhasebe Mesleğinde Etik, Aydın İlinde Muhasebeciler Üzerine Bir Araştırma. Uluslararası Işsletme Ekonomi ve Yönetim Perspektifleri Dergisi, 1(3), 12-27.

Güney, S., \& Çınar, O. (2012). Serbest Muhasebeci Mali Müşavirlerin (SMMM) Etik Algıları: Erzurum Örneği. Atatürk Üniversitesi, Iktisadi ve Idari Bilimler Fakültesi Dergisi, 2(26), 91- 106.

Gür, E. (2018), Muhasebe Meslek Etiği. Adam Akademi, 8(2), 371-407.

Hacıhasanoğlu, T., \& Karaca, N. (2015). Potansiyel Muhasebe Meslek Mensuplarının Hile Algısı Üzerine Bozok Üniversitesi'nde Yapılan Bir Araştırma. Niğde -Üniversitesi İIBF Dergisi, 8, 117-130.

İşgüden, B., \& Çabuk, A. (2006). Meslek Etiği ve Meslek Etiğinin Meslek Yaşamı Üzerindeki Etkileri. Ballkesir Üniversitesi Sosyal Bilimler Dergisi, 9(16), 59-86.

Jafarova, S. (2009). İşletmelerde Hile Yapmanın Nedenleri ve Sosyal Psikoloji Açısından Değerlendirilmesi. Yüksek Lisans Tezi. İstanbul: Marmara Üniversitesi.

Kamu Gözetim Kurumu (2015). Bağımsız Denetçiler İçin Etik Kurallar. (Erişim: 18.02.2020), https://www.kgk.gov.tr/Portalv2Uploads/files/Duy urular/v2/TDS/ET\%C4\%B0K\%20KURALLAR/2 019_etikkurallar.pdf

Kandemir, C. (2010). Muhasebe Hilelerinin Ortaya Çıkarılmasında ve Önlenmesinde Bă̆ımsız Denetimin Rolü ve Băğmsız Denetçinin Sorumluluğu. Doktora Tezi. Adana: Çukurova Üniversitesi.

Katona, G., \& Donald J. H. (1978). Behavioral Economics, M. E. Sharpe, Inc. 21(4), 14-18.

Kaya, A. (2016). Muhasebe Meslek Mensuplarının Meslek Etiği Hakkındaki Düşüncelerine İlişkin Elazığ'da Bir Araştırma., International Journal of SocialScience, 52, 183-199.
Kaya, N., \& Yanık, R. (2011). Muhasebe Meslek Ahlâk1, Etik Ve Müşteri Tatmini İlişkisi. Ekev Akademi Dergisi, 49, 293-306.

Kısakürek, M., \& Alpan, N.(2010). Muhasebe Meslek Etiği ve Sivas İlinde Bir Uygulama. Muhasebe ve Finansman Dergisi, 47, 213-228.

Kirik, Z. (2007). Muhasebede Hata ve Hileleri Ile Muhasebe Mesleğinde Etik: Afyonkarahisar'da Muhasebeciler Üzerine Bir Araştırma. Yüksek Lisans Tezi. Eskişehir: Anadolu Üniversitesi.

Korucu, E.(2018). Muhasebe Hata ve Hileleri Ile Muhasebe Mesleğinde Etik, Yüksek Lisans Tezi. İstanbul: Işık Üniversitesi.

Okay, S. (2011). Muhasebe Hata ve Hilelerinin Meslek Etiği Açısından Irdelenmesi. Yüksek Lisans Tezi. Karaman: Karamanoğlu Mehmetbey Üniversitesi.

Okutan, E., Şule, Y., \& Filiz, K. (2013). İş Hayatında Tükenmişlik Sendromu: Finans ve Muhasebe Çalışanlarının Tükenmişlik Düzeylerinin Belirlenmesine İlişkin Bir Çalışma, Çankırı Karatekin Üniversitesi İktisadi ve İdari Bilimler Fakültesi Dergisi, 3(2), 1- 17.

Organ, İ., \& Yeğen, B. (2013). Vergi Bilinci ve Vergi Ahlakı Oluşumunda Muhasebe Meslek Mensuplarının Rolü: Adana Örneği. Atatürk Üniversitesi İktisadi ve İdari Bilimler Dergisi, 27(4), 241-271.

Otto, A. M. C. (2009). The Economic Psychology of Adolescent Saving”, University of Exeter. (Erişim: 10.04.2017).

http://eric.exeter.ac.uk/exeter/bitstream/10036/838 73/3/OttoA.pdf

Özçelik, H., Aracı, N. Ö., \& Keskin, S. (2017). Muhasebe Hata ve Hileleri: Meslek Mensupları Üzerine Bir Araștırma. Süleyman Demirel Üniversitesi Sosyal Bilimler Enstitüsü Dergisi, 29, 197-214.

Özyürek, H. (2012). Muhasebe Meslek Mensuplarında Etik: Ankara'da Muhasebeciler Üzerine Araştırma. Hukuk ve İktisat Araştırmaları Dergisi, 4(1), 125 137.

Soylu, A. (2018). Muhasebe Meslek Etiği Ve Muhasebe ve Denetim Meslek Mensuplarının Etik Algısı Üzerine Bir Araştırma. Yayımlanmamış Yüksek Lisans Tezi. İstanbul: Işık Üniversitesi.

Şentürk, H.(2014). Suç ve Suçluya Dair Psikolojik Analiz. Çağın Polisi Dergisi, 150, 50-63.

Tarhan Mengi, B. (2012). Hile Denetiminde Yetkinliklerin Değerlendirilmesi-Hile Karosu. Mali Çözüm Dergisi, Kasım-Aralık

Türker, M. (1995). Muhasebe Mesleğinin Bugünkü Konumu ve Geleceği. Mali Çözüm Dergisi, 32, 16 - 22.

Varıcı, İ. (2012). Hileli Finansal Raporlama Açısından Denetçinin Sorumluluğu: İMKB'de Faaliyet Gösteren İşletmelerin Denetim Raporlarının Incelenmesi. Gümüşhane Üniversitesi Sosyal Bilimler Elektronik Dergisi, 5, 122-144. 
Yel, T. (2018). Muhasebe Meslek Mensuplarının Meslek Etiği Hakkındaki Görüşlerine İlişkin Bolu'da Bir Araştırma. AIBÜ̈ Sosyal Bilimler Enstitüsü Dergisi, 18(2), 165-184.

Yıldız, G. (2010). Muhasebe Mesleğinde Meslek Etiği ve Kayseri İl Merkezinde Bir Uygulama. Erciyes
Üniversitesi İktisadi ve İdari Bilimler Fakültesi Dergisi, 36, 155-178.

Yücel, E. (2017). Muhasebe Meslek Mensuplarının Etik Dışı Davranışlarının Vergi Ahlakına Etkisi. Muhasebe ve Finansman Dergisi, 73: 229-248. 